$10-7-2015$

\title{
Explaining the Arab uprisings: Transformations in Comparative Perspective
}

Steven Heydemann

Smith College, sheydemann@smith.edu

Follow this and additional works at: https://scholarworks.smith.edu/mes_facpubs

Part of the Near and Middle Eastern Studies Commons

\section{Recommended Citation}

Heydemann, Steven, "Explaining the Arab uprisings: Transformations in Comparative Perspective" (2015). Middle East Studies: Faculty Publications, Smith College, Northampton, MA.

https://scholarworks.smith.edu/mes_facpubs/1 


\title{
Explaining the Arab uprisings: transformations in comparative perspective
}

\author{
Steven Heydemann
}

Middle East Studies, Smith College, USA

\begin{abstract}
Drawing on the research presented by contributors to this special issue, this article assesses the analytic opportunities that emerge when the Arab uprisings are conceptualized as moments of transformation rather than as incipient, flawed or failed transitions to democracy. Highlighting critical issues that cut across and link the experiences of political relevant elites (PREs) and mobilized publics in the cases of Egypt, Libya, Tunisia, and Yemen, it identifies three sets of issues that warrant further comparative research: the effects of stateness and patterns of state-society relations on the trajectory of Arab uprisings; the role of identity politics and nonstate forms of solidarity as drivers of political mobilization and collective action, and the impact of these forms of collective action on possibilities for establishing stable, legitimate forms of governance; and the limits of civil societies and civic sectors in influencing transformational processes.
\end{abstract}

\section{From transitions to transformations}

For a brief moment in early 2011, the Middle East seemed poised to slip free of its authoritarian moorings. The mass uprisings that swept across the region in late 2010 and early 2011 created unprecedented possibilities for political openings of a kind the Middle East had never previously experienced. Less than a year before the uprisings began, Larry Diamond, a prominent scholar of democratic transitions, characterized the Middle East as 'a striking anomaly - the principal exception to the globalization of democracy' (Diamond, 2010: 93). By early 2011, as protests gathered momentum, and demands for voice, dignity and justice spread from Tunisia to Egypt and onwards across Yemen, Bahrain, Libya and Syria, an end to the Arab world's exceptionalism appeared to be at hand. Within a matter of weeks, presidents-for-life Zine al-Abidine Ben Ali of Tunisia and Hosni Mubarak of Egypt had been forced from office. By year's end, they would be joined by Ali Abdullah Saleh of Yemen and Muammar Qadhafi of Libya.

CONTACT Steven Heydemann steven.heydemann@gmail.com @ 103 Seelye Hall, 2 Seelye Drive, Northampton, MA 01063, USA 
In all four countries, the removal of entrenched incumbents initiated transitions similar to those that occurred in other cases of authoritarian breakdown and democratization. Political parties that had previously been repressed, Islamist parties in particular, now entered the political arena, joined by dozens of other newly formed political groupings. Civil society organizations proliferated. Interim authorities organized competitive multi-party elections, oversaw processes of constitutional reform and, in Tunisia, Libya and Yemen, implemented or prepared for national dialogues to underscore the commitment of new post-authoritarian regimes to inclusion and participation as they redefined the political 'rules of the game'. Even as the scope for political participation expanded, regime elites and their opposition counterparts in all four cases engaged in backroom negotiations to define the terms of transitional pacts, informal manoeuvring that would prove more consequential than developments in the electoral arena in determining the trajectory of Arab uprisings.

Yet very early on it was apparent that events unfolding in the Middle East differed from earlier experiences of democratization (O'Donnell \& Schmitter, 1986), perhaps best exemplified by the revolutions of 1989 in Eastern Europe and the Soviet Union. As Lucan Way argued in October 2011, 'The similarities and differences with 1989 suggest that more autocrats [in the Middle East] will hang on in 2011, and that those countries which do witness authoritarian collapse will be less likely to democratize than their European counterparts were' (Way, 2011: 17). To the distress of democracy advocates across the region, Way's pessimism has been borne out. Democratic possibilities faded almost as rapidly as they had appeared. By mid-2013, Egypt's first democratically elected president was ousted in a military coup. Transformations in Libya and Yemen sparked violent conflict that soon escalated into full-scale civil war and the breakdown of state institutions. Only in Tunisia did mass protests pave the way for a process of democratization. Barring the Tunisian case, the Arab uprisings have led in only two directions: state collapse in the midst of violent conflict, as in Libya, Yemen and Syria, or an 'Arab Thermidor' and the reassertion of authoritarianism, as in Egypt, Bahrain and a majority of Arab cases in which protest movements initially arose (POMEPS \& LSE, 2015).

These experiences raise important questions. Does the reassertion of authoritarianism in some cases reinforce or undermine arguments about Arab exceptionalism and the structural, institutional and economic obstacles to democratization in the Arab world (Anderson, 1995; Stepan \& Robertson, 2004; Waterbury, 1994)? Can the transitology literature inform our understanding of the uprisings and their effects on states, regimes and societies in the Middle East given the differences between the Arab uprisings and other experiences of authoritarian breakdown and democratization? How do we account for the astonishing divergence evidenced in the trajectories of Yemen and Libya (state collapse and violent conflict), Tunisia (democratization) and Egypt (authoritarian reassertion)? 
Even if the uprisings did not destabilize the regional political landscape to the extent that some observers initially suggested (Dabashi, 2012), questions remain concerning how to account for their impact and the dynamics they unleashed. Seen solely through the lens of authoritarian persistence or failures of democratization, much of what changed as a result of the uprisings is all too easily overlooked, including the emergence of new forms of political mobilization from below (Sadiki et al., 2013; Langohr, 2015; Salime, 2015; Harders, 2015); the rise, collapse and reconfiguration of new political coalitions; and fundamental shifts in conceptions of political legitimacy, citizenship and statesociety relations. Why, in some cases, did uprisings disrupt existing structures of power and bring new actors to the fore, including previously marginalized civil society actors, while in others they seemed to reinforce established elites? How can one explain new patterns of mobilization and contestation that have shaped political arenas in very different ways across the region? What accounts, in particular, for the inability of newly mobilized civil society actors to sustain effective patterns of political engagement as uprisings move from mass protests to more formal modes of political struggle?

This 2016 issue of Mediterranean Politics represents a significant step forward in developing a coherent and empirically rich analytical framework for addressing such questions. It improves our understanding of the very complex local dynamics that have driven uprisings towards such diverse outcomes across the four cases in which protesters successfully forced authoritarian incumbents from office. Yet the specifics of each case also provide the foundations for useful generalizations about patterns that have emerged in how the uprisings have unfolded thus far. The individual case studies are nuanced and strongly grounded in keen and sober assessments of local dynamics. When read together, the whole becomes more than the sum of its parts. In the aggregate, the articles in this special issue offer critical starting points for understanding both the micro-dynamics and the macro-level trends that are driving political change in the post-2011 Middle East.

Updating and extending an earlier project of the Stiftung Wissenschaft und Politik (SWP) on elites and political change in the Middle East (Perthes, 2004), the editors of this special issue (and organizers of a multi-year project that sponsored the research presented here) have made significant adjustments in the analytical framework to account for the emergence, or re-emergence, of mass politics in the Arab world and the appearance of newly empowered political actors from outside the ranks of established elites. While retaining the focus of SWP's earlier project on politically relevant elites (PREs), the editors expanded the scope of their work to include an additional category, mobilized publics, recognizing that the boundaries between the two are fluid and that how either set of actors is defined is heavily context dependent. To identify and assess major trends at both levels and capture interactions between them, the special issue includes paired studies for each case, with one focusing on the PRE and 
the other on mobilized publics. They are organized around a common set of questions but approached by the authors with sufficient flexibility to accommodate the specifics of each case and their differently configured cohorts of PREs and mobilized publics.

In 2004 a central concern of SWP's Arab elites project was leadership transition in the context of consolidated authoritarian regimes. A decade later conceptualizing the political context of the Arab uprisings is a more demanding task. If the analytical vocabulary associated with the study of democratic transitions (Sadiki et al., 2013) is inappropriate, and the lens of authoritarian regression too narrow, how can one more effectively frame an assessment of the uprisings and their aftermath? For the editors and authors of this special issue, the challenge is how to capture the dynamism of the uprisings and their effects without implying either that Arab states are moving in a linear if bumpy transition towards a visible if dimly perceived outcome or that the uprisings were a moment of sound and fury signifying relatively little. Their response to this challenge, in part, is to frame the uprisings as moments of transformation rather than transition.

The distinction between these terms is important. The term transformation captures the notion of systemic change yet without implying directionality or some form of democratic teleology. It emphasizes the fluidity and unpredictability of transformational settings, a point the editors stress in their introduction. Like much of the early transitions literature, it provides considerable scope for contingency and agency. It acknowledges 'the high degree of indeterminacy embedded in situations where unexpected events ... insufficient information, hurried and audacious choices, confusion about motives and interests, plasticity, and even indefinition of political identities, as well as the talents of specific individuals' all have an effect in shaping outcomes (O'Donnell \& Schmitter, 1986: 5). As in the transitions literature, the uncertainty and fluidity expressed by the concept of transformation must be conditioned by attention to the constraints that narrow choice, attenuate agency and impose outer limits on contingency.

However dynamic and fluid they might be, transformational spaces are nonetheless structured and shaped by their contexts. In this special issue, context affects transformational processes in a number of ways. One is through the effect of authoritarian legacies on the course of post-uprising politics, including the legacies of de-institutionalization, as in Libya and Yemen, as well as the social and political legacies of deeply institutionalized authoritarian systems of rule, as in Egypt. In all four cases, the shadow of the past looms large over transformational processes. A second is the effect of the various actors' identities - including sectarian, tribal, class, urban-rural and geographic - and how these intersect with and complicate efforts to establish stable, legitimate forms of government. In addition, the editors and authors for this special issue place particular emphasis on the resources that actors can mobilize as they struggle to advance their interests, including material, institutional, symbolic, coercive, reputational and relational resources. 
Approaching transformation processes as indeterminate and opening new space for contestation and agency, yet nonetheless bounded by resource constraints and the institutional, structural and social endowments of PREs and mobilized publics, has significant implications for the case studies presented here. To unpack and impose a measure of analytical clarity on transformational processes that were often dizzyingly complex, fast-moving and volatile, the authors emphasize thick description, process tracing (sometimes more implicit than explicit) and within-case comparisons between elements of the PRE and mobilized publics to test hypotheses (also sometimes more implicit than explicit) that account for variation in the capacity of specific PREs or mobilized publics to advance their interests. As Muriel Asseburg and Heiko Wimmen highlight in their introduction, the case studies were designed to identify configurations of both PREs and mobilized publics with several goals in mind: to map out how they interact as transformations unfold; identify what resources they bring to bear as they navigate the uncertainties of transformational moments; and assess their capacity to influence the course of transformational processes.

The critical advantage of this approach lies in the rich and fine-grained empirical data concerning specific groups of PREs and mobilized publics on which the authors base their analyses, giving them exceptional insight into micro-level dynamics. Moreover, when read as a whole, the articles offer insight into broader patterns that suggest a number of generalizable features of the Arab uprisings and the transformations they set in motion. They provide the necessary empirical and analytical foundations for moving from within-case comparisons of segments of PREs and mobilized publics to cross-case and even cross-regional research that further advances understanding of the Arab uprisings as transformational processes.

\section{Patterns of protest}

The case studies presented here provide abundant material for a comparative research agenda. Three issue areas in particular stand out as warranting attention: the effects of stateness and patterns of state-society relations on the trajectory of Arab uprisings; the role of identity politics and non-state forms of solidarity as drivers of political mobilization and collective action and the impact of these forms of mobilization on possibilities for establishing stable, legitimate governing coalitions; and the limits of civil societies and civic sectors in influencing transformational processes.

\section{Weak states and strong societies?}

In his now classic work on state-society relations in the developing world, Migdal (1988) used Egypt among other cases to argue that societies in many seemingly strong states had highly developed capacities to resist centralizing 
projects designed to secure the compliance of citizens through imposed, topdown rules of the game. Challenging then current theories of state autonomy, Migdal developed a'state in society' approach to underscore the social embeddedness of state actors and the extent to which state elites and social actors engaged in contestation over the boundaries and limits of state power (Migdal et al., 1994). The Arab uprisings suggest the value of returning to and revisiting Migdal's framework. The case studies presented here make clear that stateness matters in understanding variations in the strategies of PREs and mobilized publics and in the larger trajectories of the Arab uprisings. Both the degree of stateness and the specific forms through which stateness manifests itself are important in ways that Migdal did not fully anticipate.

In Libya, the Qadhafi regime rejected the formation of a large, formal, consolidated state apparatus With the exception of the security apparatus (al-Mukhabarat) and petroleum sectors, Qadhafi pursued an explicitly anti-institutional, dispersed strategy of governance based on the use of clientelist networks linked to favoured tribes and regions to shore up his regime (Vandewalle, 2008) In Yemen, President Saleh used stateness as a bargaining chip in his negotiations with key elites who viewed state institutions as a desirable resource (Alley, 2010) By withholding or granting the expansion of state institutions and programmes into areas in which potential rivals held sway, Saleh preserved his pre-eminence as power broker, mediator and bestower of privilege In both cases, state weakness was an intentional result of regime-building strategies that relied on empowering and enriching select cohorts of social actors, marginalizing others and preventing the emergence of strong states around which opposition actors might coalesce.

As the articles by Wolfram Lacher and Mareike Transfeld on Libya and Yemen, respectively, make clear, under these conditions it is not surprising that once uprisings began, patterns of political mobilization among the PRE quickly became organized around existing, principally tribal, social cleavages. It is also unsurprising that state elites (itself a problematic category) would lack the institutional capacity to check the escalation of social conflicts or, indeed, to hold underdeveloped and weakly consolidated states together in the face of rising violence - not least because states themselves have been captured for the political and material benefit of predatory elements of the PRE. Migdal views strong societies as a valuable check on the grandiose ambitions of state elites. Yet where states are too weak to prevent or regulate violent social conflicts, where states have been captured by social groups and where societies mobilize around multiple, competing non-state, non-citizen-based identities and solidarities, moments of transformation seem all too likely to produce state collapse and violent conflict. Defining and then institutionalizing an appropriate balance between state and social power - the elusive 'participatory social contract'that national dialogues were intended to generate - seems beyond the political will or capacity of super-empowered non-state actors in both Libya and Yemen. 
Despite such conditions, however, Lacher and Transfeld also show that it would be a mistake to conclude that non-state actors have no use for the state. Indeed, in both Yemen and Libya, control of the state remains a focal point of social conflict. In both cases, conflicts among PREs and mobilized publics alike are driven by differences over whose interests will prevail in shaping or reforming state institutions and defining new rules of the game. The Libyan case is perhaps most striking in this regard. Despite the de-institutionalized legacy of Qadhafi's rule, the state remains a ghostly presence throughout Lacher's account. In the midst of state collapse and civil war, for example, fighters continue to receive state salaries, the sale of oil continues through nominally sovereign entities, and factions compete for international recognition as legitimate state authorities.

Egypt and Tunisia provide sharp contrasts to the Libyan and Yemeni cases and differ with each other in important ways. In both, transformational outcomes are contingent on struggles among competing elements of the PRE for control of consolidated states. In both, non-state identities and solidarities are present yet play a subordinate role in transformational processes. Amel Boubekeur highlights the role of elite'pact making' as a critical feature of Tunisia's transformation. She views the effectiveness with which PREs manoeuvred behind the scenes to negotiate a division of power within the state apparatus and political institutions as corrosive of Tunisia's emerging democracy. Yet as Stephan Roll's account of Egypt highlights, the alternatives could be worse.

In Tunisia, no single element of the PRE possessed the coercive or bureaucratic resources to govern on its own. All elements of the PRE preferred compromise that preserved the state and the potential for further democratization instead of defection, conflict and potential state collapse. In Egypt, on the other hand, a pacted transition broke down under the strain of elite conflict, leading to the reassertion of authoritarianism. Competition between the ruling Muslim Brotherhood and the military ended in the July 2013 coup led by the then-minister of defence and head of the armed forces, and now president, Abdel Fatah al-Sisi. Commanding the coercive and bureaucratic resources to govern on its own (Kandil, 2012), and confronting the imposition of an illiberal democracy (at best) by Muslim Brotherhood leader and Egyptian president Mohammed Mursi, the military preferred to defect from a ruling coalition with the Brotherhood and bring Egypt's democratic transition to a close. One set of state actors, the military, was sufficiently strong to impose rules of the game on both PREs and mobilized publics.

In all four cases, questions about the effects of stateness on transformational processes and how the degree of consolidation of state institutions, the structure of state-society relations, the extent to which shared conceptions of citizenship and legitimacy organize mobilization and collective action among PREs and mobilized publics offer important opportunities for more broadly framed comparative research. 


\section{Identity politics and the challenge of governance}

Egypt and Tunisia also stand apart from Yemen and Libya in the role that nonstate identities and solidarities have played in transformational processes. In neither case have non-state, non-citizenship-based political identities become a dominant axis around which political conflicts among the PRE or mobilized publics organized. Such identities are certainly present in both, as are conflicts over competing conceptions of citizenship, legitimacy and the sources of political authority. Yet relative to Libya and Yemen, identity-based conflicts have been secondary to struggles over control of the state.

In Libya and Yemen, non-state identities and solidarities - whether sectarian, ethnic, tribal, regional or combinations of these - have emerged as central fault lines, as they have in Syria and Bahrain. For PREs and mobilized publics in Libya and Yemen, these identities and solidarities have long been consequential in shaping political dynamics: with the Arab uprisings they became core 'pivots' anchoring and organizing transformational spaces, largely determining patterns of political mobilization and social conflict. In some respects, such developments challenge the notion of transformations developed in this special issue as moments of uncertainty and contingency. To the extent that the Libyan and Yemeni uprisings have merely amplified long-standing political divisions among established tribal PREs by weakening the capacity of (already weak) states to regulate conflict, the scope for either agency or contingency would seem to be highly constrained.

In regard to the politics of alliance formation and coalition building, however, it is clear that agency, contingency and uncertainty remain defining features of transformational processes, including in cases where non-state identities exert a powerful influence on the strategic calculus of PREs and mobilized publics. The essays by Lacher and Transfeld on PREs in Libya and Yemen and by Nadine Abdalla and Rafaa Tabib on mobilized publics in these two cases provide sophisticated and fine-grained analyses of bargaining dynamics among competing tribal, ethnic, regional and class interests. Their accounts underscore the challenge of building stable, legitimate, cross-cutting political coalitions in the absence of broadly accepted rules of the game and viable state institutions and where non-state identities impede efforts to build political communities around widely shared conceptions of legitimacy and citizenship. They also pose an additional challenge to Migdal: in the absence of viable states, struggles over rules of the game are less likely to develop as expressions of resilience and pluralism than of fragility and potential conflict. Despite variation in the resources that different elements of the PRE command, the ease with which weaker groups can destabilize attempts to reach consensus - especially when every element of the PRE is heavily armed - makes transformational moments under such conditions particularly fraught. Yet these essays also make clear that the conflicts now tearing Yemen and Libya apart were not in any sense preordained. In every respect, they are the product of specific decisions by identifiable actors 
who had meaningful scope for deciding how they might respond to the challenges of managing a post-Saleh or post-Qadhafi transformational process. Both cases provide ample support for the agent-centred and choice-based model of transformational processes presented in the introduction to the special issue.

Libya and Yemen are not doomed to futures as failed states. Neither is unique in wrestling with the challenges of governance in a divided society or in confronting obstacles to the formation of a shared conception of political community, however constructed and imagined such communities might be. Both issues have been the subject of voluminous research literatures. Understanding how similar conflicts have unfolded in other cases, in particular how other sharply divided societies have found pathways out of civil war and towards processes of social repair and state reconstruction, is an area in which broader cross-case and cross-regional comparisons would be both eminently feasible and especially helpful.

\section{The limits of mobilized publics}

Among the most striking features of the Arab uprisings is the failure of the mobilized publics that played such an important role in launching protest movements to sustain their influence once the focus of transformations shifted from streets and public squares into formal political arenas. The case studies presented here on mobilized publics in Tunisia, Egypt, Yemen and Libya tell remarkably similar stories. They also confirm the experiences of other, non-Middle Eastern cases in which activists struggled to transform social movements into political structures able to compete effectively after the street-level protests gave way to electoral competition. Each author profiles civil society groups and ad hoc movements that vary in their goals and objectives and in their relationships with established and newly empowered, more oppositional segments of the PRE. Each case highlights at least one element of the mobilized publics that benefited from longstanding ties to some segment of the PRE, including Anna Antonakis-Nashif's discussion of the Tunisian Association of Democratic Women, Atiaf Z. Alwazir's description of Yemen's al-Watan (Homeland) Party and Nadine Abdalla's account of Egypt's Future of the Nation Party. In each case, mobilized publics have struggled to leverage the credibility and legitimacy they acquired through their leadership of protest movements into influence over the trajectory of subsequent political transformations. In each case, revolutionary elements of the mobilized publics wrestled with the choice of remaining outside formal politics, and thus losing influence, or entering the political arena at the expense of their revolutionary credibility. In each, these struggles were internally divisive. In each, group members made different choices, with some opting to remain outside formal politics, others choosing collaboration with PREs or, in the case of the Future of the Nation and al-Watan parties, to register as formal political parties and compete in parliamentary elections. 
Despite differences in the social backgrounds and resources of the participants in these movements, in their relationships to PREs, in their choice of exit, voice or loyalty (Hirschman, 1970), virtually none of the elements of the mobilized publics profiled in these case studies succeeded in acquiring meaningful, sustained influence over the course of transformational processes. To be sure, there are some exceptions to this characterization of mobilized publics. Across the board, those individuals and groups among the mobilized publics that fared best in terms of influence were those most closely aligned with and those most willing to collaborate with and be co-opted by powerful elements of the PRE. In contrast, the more committed a civil society group or social movement was to revolutionary transformations of one form or another (economic, political, social), the more likely it was to find itself marginalized by the PRE. For most elements of the mobilized publics, participation in social movements seems to have led to frustration, cynicism, exclusion and eventual disengagement. As Boubekeur points out in this volume, some 70 per cent of Tunisian youth between the ages of 18 and 30 abstained from voting in the 2014 legislative and presidential elections. By early 2015, as the Arab uprisings entered their fifth year, it is difficult to identify any segments of the mobilized publics in the four cases covered in this special issue that can be said to have played a decisive role in shaping the trajectories of transformational processes.

This broad-based failure of mobilized publics to sustain their influence has been noted by scholars and analysts of the Arab uprisings. How to explain this outcome, however, has received less attention. Most accounts focus on shortcomings among elements of these mobilized publics, including a lack of experience and the stubborn, ultimately self-defeating refusal of leading activists to leverage their revolutionary credentials for political gain. Broader comparisons, however, might shift attention to other factors. Marc Howard's (2003) work on civil society in Russia and East Germany highlights the impact of authoritarian legacies and the challenges they pose for civil society organizations in environments in which civic engagement has long been suppressed. Amaney Jamal's (2009) work on civil society in Palestine makes similar arguments concerning the relationship between an authoritarian political environment and the lack of internal democracy within Palestinian civil society organizations. The within-case approach of the case studies presented here leans towards case-specific explanations of the limits of mobilized publics to effect change. Yet it seems very likely that these limits result from deeper structural and institutional factors that cross-case comparisons might be better equipped to identify and explore.

\section{Conclusion: transformations in comparative perspective}

The three issue areas highlighted above represent only a small sample of the rich comparative possibilities the Arab uprisings have created, none of which would be possible to exploit without the detailed empirical foundations provided by 
the contributors to this special issue. They also point to the value of approaching such comparisons through the analytical framework applied by the contributors. Conceptualizing the Arab uprisings as transformational processes without imposing on them either the expectation that they will take the form of democratic transitions or that they can be adequately explained simply as cases of failed democratization is important for avoiding deterministic or essentialist traps. Acknowledging the uprisings as having opened up political space, created new political possibilities and empowered new political actors is a more productive starting point for understanding what is actually happening on the ground than research weighed down by the conceptual baggage of theoretical constructs that do not fit the cases at hand. The essays included here provide compelling narratives of political struggles the outcomes of which could not be predicted in advance, not least by those who took part in them.

The uprisings have been described as a political earthquake. If they left a recognizable landscape in their wake, they have nonetheless marked it in indelible ways. Acknowledging that conditions made a democratic wave unlikely in the Middle East does not relieve analysts of the challenge of explaining how the uprisings unfolded or of accounting for the variation in both their trajectories and their outcomes. The essays in this special issue mark a significant advance towards these goals.

Similarly, the focus on PREs and mobilized publics and the interactions between them provides a useful analytical starting point in several ways. It requires a detailed mapping of relevant actors that is evident in the work of the contributors to this special issue. Consistent with the editors' conceptualization of transitional processes as moments of uncertainty, it draws attention to agency and contingency in accounting for outcomes. It also provides analytical categories sufficiently broad and flexible to accommodate analysis of relevant actors however they might be situated within a transformational space. As this suggests, the concepts of PRE and mobilized publics must be used with care. Assigning actors to one category or another tells us relatively little in and of itself about how any specific actor or group will behave. The boundaries between them will not always be easy to discern. All of the case studies presented here include examples of individuals who move from one category to the other. Yet used appropriately, they hold considerable promise as a starting point for unpacking the micro-dynamics of complex contexts like the Arab uprisings and for effective within-case and cross-case comparisons.

A useful next step for a research on PREs and mobilized publics in the Middle East is to build on the case studies presented here to advance a broader comparative agenda aimed at understanding transformational processes as a category of events that exhibit any number of shared features. Such a step would shift the focus from who matters and what happened in particular cases to questions on how particular categories of PREs, such as military elites, behave during transformational processes and how to account for patterns and variation 
in their behaviour. It would permit assessment of the conditions under which mobilized publics can influence the trajectories of transformations. It would also provide a stronger basis for addressing questions about why Tunisia, alone among Arab states that experienced uprisings, has begun a meaningful process of democratization. As yet, answers to these questions remain a work in progress for scholars of the Middle East. The contributions to this special issue leave these scholars better positioned to pursue them.

\section{Disclosure statement}

No potential conflict of interest was reported by the author.

\section{Funding}

This work was supported by the German Ministry of Foreign Affairs [grant number VN 02-381.47-TP-P-03/12], [grant number VN 02-381.47-TP-P-03/14], [grant number VN02381.47-TP-P-15/15]; Robert Bosch Stiftung [grant number 11.5.2070.0195.0].

\section{References}

Alley, A.L. (2010) The rules of the game: unpacking patronage politics in Yemen, 64(3), pp. 385-409. doi:10.3751/64.3.13.

Anderson, L. (1995) Peace and democracy in the Middle East: the constraints of soft budgets, Journal of International Affairs, 49(1), pp. 25-44.

Dabashi, H. (2012) The Arab Spring: The End of Postcolonialism (London: Zed Books).

Diamond, L. (January 2010) Why Are There No Arab Democracies, Journal of Democracy, 21(1), pp. 93-112.

Harders, C. (2015) "State analysis from below" and political dynamics in Egypt after 2011, International Journal of Middle East Studies, 47(1), pp. 148-151. doi: 10.1017/ S0020743814001524.

Howard, M. (2003) The Weakness of Civil Society in Post-Communist Europe (Cambridge and New York: Cambridge University Press).

Hirschman, A.O. (1970) Exit, Voice, and Loyalty: Responses to Decline in Firms, Organizations, and States (Cambridge: Harvard University Press).

Jamal, A. (2009) Barriers to Democracy: The Other Side of Social Capital in Palestine and the Arab World (Princeton: Princeton University Press).

Kandil, H. (2012) Soldiers, Spies and Statesmen: Egypt's Road to Revolt (London:Verso Press). Langohr, V. (2015) Women's rights movements during political transitions: activism against public sexual violence in Egypt, International Journal of Middle East Studies, 47(1), pp. 131-135. doi: 10.1017/S0020743814001482.

Migdal, J.S. (1988) Strong Societies and Weak States: State-Society Relations and State Capabilities in the Third World (Princeton: Princeton University Press).

Migdal, J.S., et al. (1994) State Power and Social Forces:Domination and Transformation in the Third World (Cambridge: Cambridge University Press).

O'Donnell, G. \& P. Schmitter (1986) Transitions from Authoritarian Rule, vol. 4: Tentative Conclusions about Uncertain Democracies (Baltimore, MD: Johns Hopkins University Press). 
Perthes, V. (2004) Arab Elites: Negotiating the Politics of Change (Boulder: Lynne Rienner Press).

POMEPS and LSE (Project on Middle East Political Science and London School of Economics and Politics, Middle East Centre) (2015) The Arab Thermidor: The Resurgence of the Security State, POMEPS Studies no. 11 (Washington, DC, and London: POMEPS and LSE Project on Middle East Democracy).

Sadiki, L., H. Wimmen \& L. Al-Zubaidi (2013) Democratic Transition in the Middle East: Unmaking Power (London: Routledge).

Salime, Z. (2015) I vote I sing: the rise of aesthetic citizenship in Morocco, International Journal of Middle East Studies, 47(1), pp. 136-139. doi: 10.1017/S0020743814001494.

Stepan, A.C., Robertson, G.B. (2004) Arab, not Muslim, exceptionalism, Journal of Democracy, 15(4), pp. 140-146. doi: 10.1353/jod.2004.0067.

Vandewalle, D. (2008) Libya since Independence: Oil and State-Building (Ithaca: Cornell University Press).

Waterbury, J. (1994) Democracy without democrats? The potential for liberalization in the Middle East, in: G.Salame (Ed) Democracy without Democrats: The Renewal of Politics in the Muslim World, pp. 23-47 (London: I.B. Tauris).

Way, L. (2011) Journal of Democracy, 22(4), pp. 13-23. doi:10.1353/jod.2011.0068. 